\title{
"Gawai": Cultural Activities in the Shroud of Jangkang Bokidoh Dayak Tribe Traditional Architecture in Balai Sebut Village
}

\section{Irawan Setyabudi ${ }^{*}$, Dian Kartika Santoso ${ }^{2}$, Katarina Albina ${ }^{3}$}

${ }^{123}$ Department of Landscape Architecture, Faculty of Agriculture, Universitas Tribhuwana Tunggadewi, Indonesia.

Corresponding Author: irawan.setyabudi@unitri.ac.id

\begin{tabular}{|c|c|}
\hline & Abstract \\
\hline $\begin{array}{l}\text { Keywords: } \\
\text { Cultural Activity, } \\
\text { Dayak Jangkang } \\
\text { Bokidoh, Local wisdom, } \\
\text { Traditional } \\
\text { Architecture }\end{array}$ & $\begin{array}{l}\text { Balai Sebut Village located in Perintis Hamlet, Sanggau Regency, } \\
\text { which has indigenous people, namely Dayak Jangkang Bokidoh. Local } \\
\text { wisdom in those areas still closely held, either tangible, such as } \\
\text { traditional architectural forms, or intangible, such as traditional and } \\
\text { cultural activities. This study discusses the visual form of the } \\
\text { traditional house, the pattern of micro-space arrangement and } \\
\text { traditional activities that use the "Gawai" space. "Gawai" is a religious } \\
\text { ceremony as a sense of gratitude which involves the use of micro to } \\
\text { macro spaces. The purpose of this research is to focus on the } \\
\text { identification of house forms, settlement patterns, and cultural } \\
\text { activities that using an architectural space as an effort to preserve } \\
\text { traditional architecture which is precisely in Perintis Hamlet. The } \\
\text { research method was carried out in a descriptive-qualitative manner } \\
\text { with an ethnographic approach. Data collection was carried out } \\
\text { through a focus group discussion. The results showed that the Dayak } \\
\text { Jangkang Bokidoh tribe had architectural tangible and intangible } \\
\text { values. Physical spaces that have architectural value will have } \\
\text { meaning if there are activities that involve the space. In this case, } \\
\text { seven kinds of traditions are still preserved in Balai Sebut village, } \\
\text { namely in the form of "Gawai", which are related to the presence of } \\
\text { ancestors, gratitude for the harvest, birth, death, and marriage as } \\
\text { cultural activities that must be preserved together with the traditional } \\
\text { house. So, "Gawai" can be said as a cultural activity that gives } \\
\text { meaning to space in the traditional architecture of the Jangkang } \\
\text { Bokidoh Dayak Tribe. }\end{array}$ \\
\hline
\end{tabular}

DOI: https://doi.org/10.26905/lw.v13i1.4816

Article History Received : Sept 20, 2020

@ 2017 The Authors. Published by GKAK UNMER Malang

\section{INTRODUCTION}

Jangkang is the largest sub-district in Sanggau Regency, West Kalimantan, in the west bordering the city of Pontianak and not far from East Malaysia (Suhendro, Hanye, \& Patriantoro, 2019). The research location is located in Perintis Hamlet, precisely in Balai 
Sebut Village, Jangkang District. This village is one of the villages that still not widely touched by migrants. In ancient times, reaching the area which is now a settlement was not easy, it required energy and time because the means of transportation relied on rivers, namely the Sedua and Mengkiang rivers, which were then reached on foot across valleys, canyons, swamps and through forests which then met a village (Putra, 2012).

Majority of the population is the Jangkang Bokidoh Dayak Tribe. The uniqueness of this tribe can be seen in terms of tangible and intangible. Tangible aspects are aspects that can be observed with the naked eye, while intangible are the values that exist in a particular entity or society. (Ginzarly, Pereira Roders, \& Teller, 2019). The tangible aspect of this study can be seen from the shape of the building (Rushton, Silcock, Rogers, \& Schnabel, 2018). In the microsphere, the shape of a traditional house at a glance looks like a traditional Dayak house in general, a saddle-shaped roof, walls and floors of wooden planks, while a wooden pedestal that enters the ground up to one meter. Initially, the Dayak traditional house was in the form of an huma but transformed a betang house which was the conventional house. Settlements also experience morphological changes in line with increasing needs (Rianty \& Jurumai, 2019). In one residential corridor, the community used the slope of the land. So, the position of the road is higher than the house backyard, and a house is formed with the construction on stilts. The space formed under the house is used as a multipurpose space for storing tools such as jarai (a device made from woven bamboo and rattan to lift items which placed on the back) - alternatively, a place to store livestock, such as chickens.

The typology of houses in Balai Sebut Village is relatively kind. The only difference is the size of the house. The "inner room" of the house consists of the front and back. Meanwhile, vertically divided into top and bottom. The front is adjacent to the village road. There is a circulation space leading to the terrace. This front yard is quite wide (about 2-3 meters from the road) intended if at any time there is a development from the government, or it is used for drying agricultural products. The terrace pattern is sometimes not the same and is used as a space for business, and the living room is in the house adjacent to the bedroom, the kitchen is behind and is used as a family room. There is a rice granary with a separate mass from the small house. In the scope of the meso, the house does not have a direct border with the neighbours but has a transitional space, which is often used as access to the backyard. Human activities in the use of space either micro, meso or macro are discussed in the form of cultural activities (intangible) related to the life cycle, namely birth, death, marriage, agriculture, and other religious ceremonies . Examples of cultural activities in Balai Sebut Village are related to agricultural products, namely "Gawai" storing rice, "Gawai" seeds, "Gawai" stones, "Gawai" burong, "Gawai" antu, "Gawai" notokng, and "Gawai" thanking the harvest.

In its development, the traditional architecture of the Dayak Jangkang Bokidoh tribe in Jangkang District is no longer like a truly pure traditional house but is transformed into vernacular architecture, namely adaptive forms applying elements of culture, the environment, including the local climate, expressed in physical form Architectural (Sumalyo, 1993). The essence of vernacular architecture such as traditional house forms is a dialogue between humans and the environment, climate response, material, cultural, technological and social limitations. (Oliver, 1987). In line with that thought, Prijotomo \& Pangarsa (2010) also states that the presence of space is formed due to human activity in a place, reciprocity between humans and their natural environment; in this case, it has to do with vernacular architecture (Prijotomo \& Pangarsa, 2010).

Return to the basic definition of space which means a place for human activities. Space does not automatically exist, but there is a process of its formation, it could be due to 


\section{"Gawai": Cultural Activities in the Shroud of Jangkang Bokidoh Dayak Tribe Traditional Architecture in Balai Sebut Village \\ Irawan Setyabudi, Dian Kartika Santoso, Katarina Albina}

social factors, natural conditions, economics, Etc (Bambang, Ari, Susilo, \& Widya Fransiska Febriati, 2016). The space formed by social activities is a social space, with one example being the common space (Indeswari, Antariksa, Pangarsa, \& Wulandari, 2013). Common room, communal space or shared space as a place to accommodate various community activities (both positive and negative) in meeting needs. In the meso and macro scope, the residential environment is formed due to the process of housing formation that involves human activities, both physical and non-physical (socio-cultural) which affect the activity pattern and the process of its placement. (Rapoport, 1990). So, a common space is formed according to the environment and culture of the local community.

From the description above, it can be seen that the Dayak Jangkang Bokidoh tribe in Balai Sebut Village has cultural values that must be preserved. As stated in the UNESCO document which states that objects, movable heirlooms, and spiritual products such as music, dances, traditions also need preservation. Includes all textual phenomena and linguistic phenomena (Rushton et al., 2018). The obstacle faced is the absence of efforts from the community and local government in managing the potential of the area, which in the future could become a cultural tourism area. But as the cultural tourism area, architectural and cultural character of the area must be preserved (Santoso \& Wikantyoso, 2018). The urgency of this research is the need to identify the potential of the pioneer hamlet both in physical and non-physical terms concerning the unique traditional architecture for the Dayak Jangkang Bokidoh tribe. So, the purpose of this study focuses on identifying the characteristics of the house building form of the Dayak Jangkang Bokidoh tribe and the embodiment of the use of space for cultural activities.

\section{METHOD}

The object of the research is a residential corridor for the Dayak Jangkang Bokidoh tribe which is located in Perintis Hamlet, Balai Sebut Village, Jangkang District, Sanggau Regency, West Kalimantan Province, Indonesia. In this sub-district there are 11 villages namely Balai Sebut, Jangkang Benua, Tanggung, Banana, Empiyang, Semombat, Terati, Selampung, Sape, Semirau, and Ketori. The research limitation was only taken in Balai Sebut Village because it gave priority to villages that had unique traditions and character of semi-stilt traditional houses, which were different from other regions. When the research was carried out from August to October 2019. To simplify the observation process, here are the locations of the study objects.

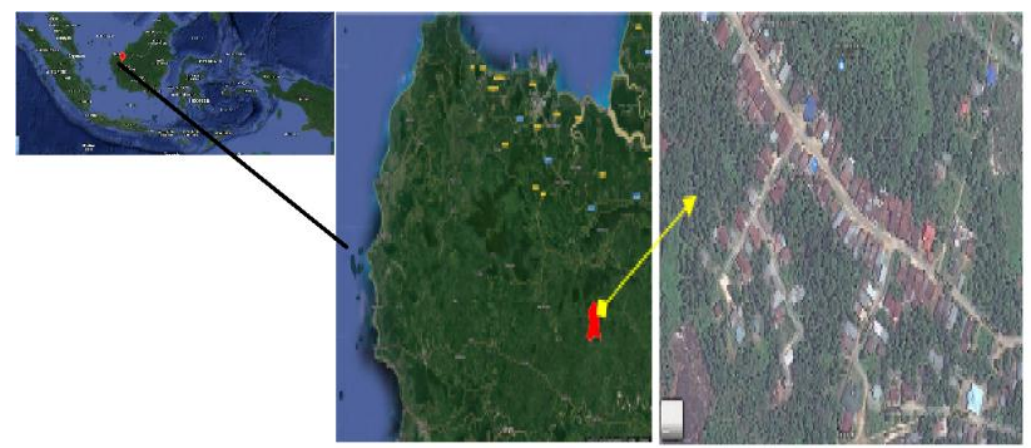

Figure 1. Research location in Perintis Hamlet in Balai Sebut Village (Source: google maps)

The research method was conducted in a descriptive qualitative manner with an ethnographic approach. The research method is to collect data following the actual situation related to the description of the events that occurred at the research location, and the next process is described descriptively to get a description and conclusions that answer the 


\section{LOCAL WISDOM, Vol. 13 No. 1 January 2021 \\ Local Wisdom Scientific Online Journal}

research problem (Bhattacherjee, 2012). Ethnography was chosen because it is necessary to know the culture of the Jangkang Bokidoh Dayak Tribe in Jangkang District, so that the spatial patterns for cultural activities can also be known. In line with research conducted by several other studies (Fitriyani, Antariksa, \& Wulandari, 2015; Indeswari et al., 2013; Wijaya, 2020), a qualitative descriptive research flow was conducted by direct observation of the research object, and data was collected through interviews and focus group discussions with the local community (Creswell, 2014). The data obtained is in the form of information about the architecture of the houses, history and culture of the Dayak Jangkang Bokidoh community. The descriptive approach obtained a description of how the characteristics of the traditional houses of the local community along with the use of space which begins with the identification of cultural activities related to the life cycle and religious events, namely "Gawai". The house samples were selected purposively, which were considered to represent the shape of the house in a residential corridor. The process of explaining visual descriptions with computer software, namely SketchUp 2020 or sketches to make it easier to describe. The factors that influence or cause the formation of the common space are activity, time and place, while the factors that become the effect are the shared space pattern. Furthermore, the identification results are analyzed in relation to the relationship between architecture and the use of space by referring to the related theory so that a conclusion can be drawn. Research stages shows in Fig.2.

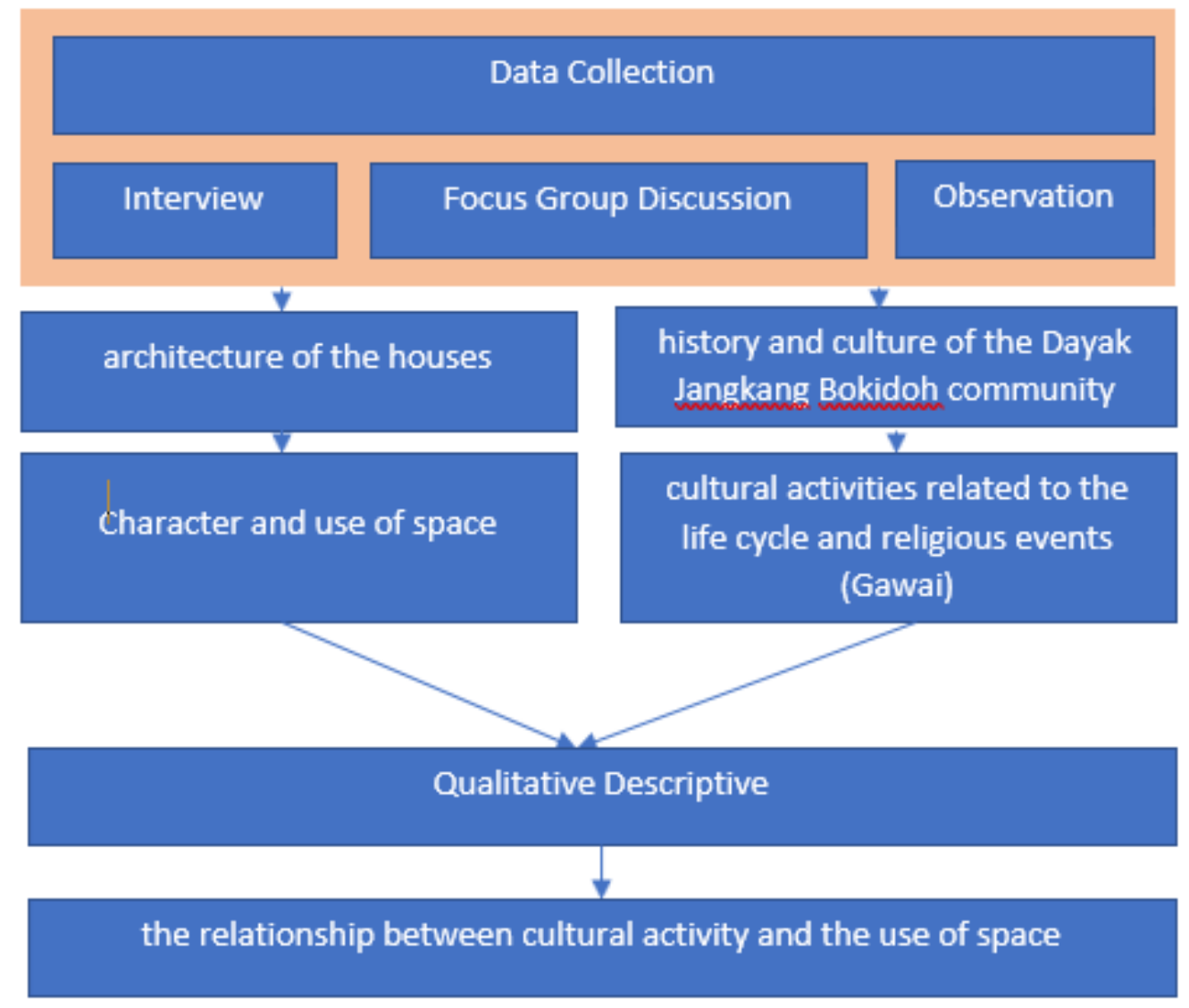

Figure 2. Research stage

(Source: author) 


\section{"Gawai": Cultural Activities in the Shroud of Jangkang Bokidoh Dayak Tribe Traditional Architecture in Balai Sebut Village \\ Irawan Setyabudi, Dian Kartika Santoso, Katarina Albina}

\section{RESULT AND DISCUSSION}

\section{History of Settlements}

The Dayak tribe is the original tribe of the island of Borneo. This is evidenced by the relics of ancient objects from the Neolithic era, in the form of stone axes and broken earthen pots (Putra, 2012). Thus, the area of West Kalimantan at that time was already inhabited by humans. The indigenous people of the island of Borneo are called Dayaks and adhere to the original religion, while those who adhere to Islam are called Sinan or Senganan, which is mistaken for the Malay ethnic group even though they are not of Malay descent.

The origin of the Dayak Jangkang is a splinter group of Dara Nante and Babai Cinga who experienced obstacles on the Sekayam River on their way to Tampun Juah. After several days of meeting, Dara Nante's group returned to Sanggau and headed to Labai village leaving her husband. Tampun Juah is a busy settlement, but socio-economic problems arise, especially food. The Engkarong tribe originating from Tampun Juah left the area for Tampun Entabai and after that became nomadic, settling for a long time in Nanga Solabau. After that, move upstream again, namely the Nanga Sungai Sobut until they meet the Malays. Then they bartered. The area is a comfortable place to anchor and has quite a lot of inhabitants. There was also a base where people used to exchange merchandise, so it was called a 'hall'. Balai Sebut means a place where people meet and transact with each other on the Sobut river. The Mengkiang River before the 1990s was the primary function of trade and transportation, apart from being a place for bathing and washing, but its cleanliness was well maintained. The relationship between Malay and Dayak is very close, that is, like their own family.

The origin of Jangkang comes from a village, namely Ponongu, which is located in Tabao. In Ponongu, there are two villages where there is usually an agreement, that is, if the harvest is finished, a "Gawai" party will be held, but at that time there was a reason that "Gawai" was not carried out. At that time, the two villages were separated by a road so that they became left and right villages. There was an incident that caused the village to disband, while the residents moved to another location looking for new settlements. There are those who go upstream to meet the Ence river which is the forerunner of the Jangkang people. They initially did not settle in the current Jangkang area but in Botuh Logunt. However, one day there was pestilence (epidemic), as a result of this incident, so he moved to Songongk. In that area, the people were not friendly enough, so they had to move to Polumpor. Finally, he built a permanent house, namely Ompuk Jongkang because it is located near the Jangkang spring. Like the name Jangkang Benua, which comes from the name of wood and tributaries. Meranti wood in the Jangkang language is called tokamp, there are many kinds, one of which is Tokamp Jangkang. This wood thrives in the Ence River. That is why it is called the Jangkang river and the village is called the Jangkang village, while the inhabitants are called the Jangkang Dayak Tribe.

\section{Existing Conditions}

The landscapes in Jangkang District are as follows. The topography is on predominantly flat land with several slopes and steep slopes. The climate is tropical, seen from BPS statistics for the last 5 years, the most rainfall was in 2018 with an average of 314.2 $\mathrm{mm}$ and 14 rainy days. This area is an area that significantly utilizes the land around it which can be seen from fair land use in terms of agriculture, plantations and settlements. 


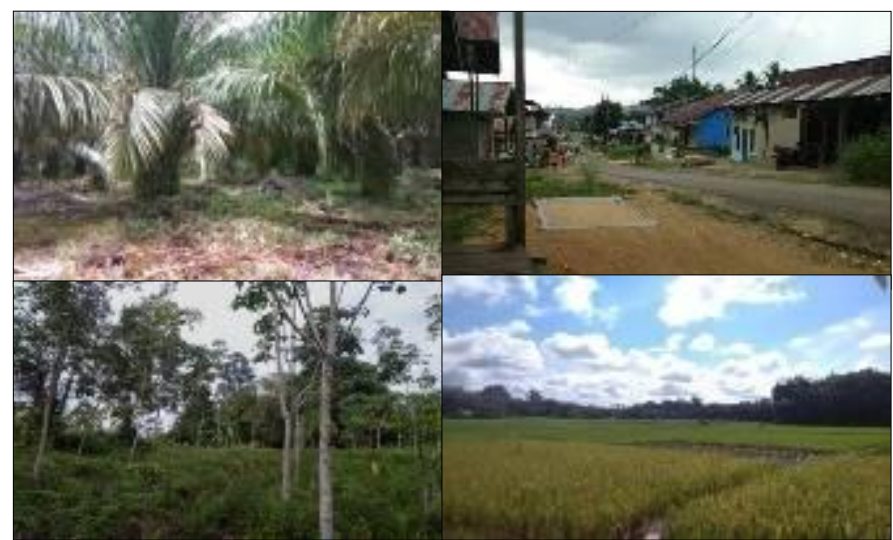

Figure 3. Land Use in Jangkang District (Source: author)

In Perintis hamlet, the village orientation extends along the road from northwest to southeast. The space between the curb and the house is about 3 meters and can be used for drying agricultural products. Agricultural areas are located not far from settlements, and residents usually collect agricultural produce in the barn behind the house. The position of the road is higher than house's back yard So that it forms the space under the house with the construction on stilts. There is specific vegetation around the settlements, namely cempedak trees (such as jackfruit), kapuak (as a primary material for Dayak traditional clothes), tengkawang (the primary material for making houses and oil), palm and sahang (source of livelihood), resam (the base ingredient for spices), rattan (accessories material). At each village boundary, there is a cross which implies a devout community. Likewise, in terms of tradition, it is still closely held, namely the existence of "Gawai" activities. This activity involves all residents and village officials and in using space at the macro level to attract all residents to come to see and have the tourism potential.

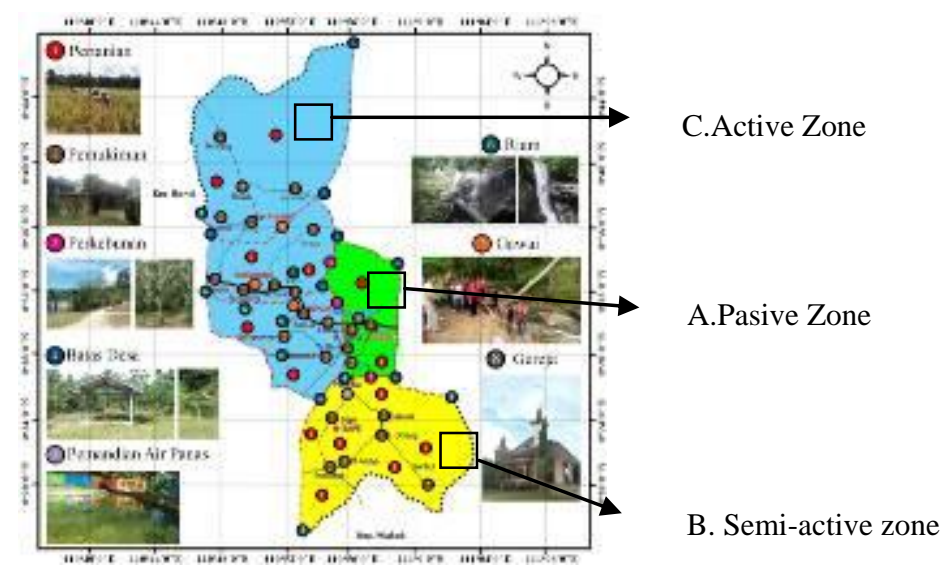

Figure 4. Division of Tourism Zones in Jangkang District

(Source: analysis result)

One of the results of the research that has been carried out and based on the results of the focus group discussion is the division of tourist zones in Jangkang sub-district. The three zones obtained are active, semi-active and passive zones. The active zone has elements of pure culture. The locations are in Pisang Village, Tanggung Village and Jangkang Benua Village. People still maintain traditions and beliefs in everyday life. The semi-active zone is a zone that has powerful natural resources such as natural visuals in 


\section{"Gawai": Cultural Activities in the Shroud of Jangkang Bokidoh Dayak Tribe Traditional Architecture in Balai Sebut Village \\ Irawan Setyabudi, Dian Kartika Santoso, Katarina Albina}

Sape Village. In this zone, tourists are only allowed to enjoy its natural beauty, namely by going to the Sipan Lotup hot springs. This area is not as thick as the active zone. Meanwhile, the passive zone that has received acculturation by outside cultures who live there. So many aspects of the culture are starting to be abandoned. Tourists are limited to only doing tourist activities in this passive area because it is a taboo if done inactive and semi-active zones. Balai mentioned village is located in this passive zone which requires preservation action for the historic area.

\section{The traditional architecture of the Jangkang Bokidoh Dayak Tribe}

The study begins with a micro scope, which is related to traditional houses in Balai Sebut Village. As explained by Rianty \& Jurumay (2019) that the morphology of the house comes from huma, with a tent-like shape and stepping on the ground, then transforming into Betang crust. One family conventionally inhabits this house model, its constituent elements are about 1-2 meters high, 8-15 meters long, 6-8 meters wide, orientation of its placement with the length or width of the house parallel to the river. The pole material is made of round iron wood, and the walls are made of bark clamped with rattan slices, the door is in the middle of the main building, the shape of a saddle roof is made of the iron shingle. There are several things that distinguish the conventional Betang Kerak from the traditional houses in Balai Sebut Village because it has become a vernacular formation, in which the orientation of the settlement faces the village road instead of the river, and the side of the road is higher than the backyard. The door is located in the middle of the building, but the terrace tends to change its function due to necessity, it can be used as a warehouse or other function.

Based on the results of surveys and observations, the house samples were selected in Mr. Yohanes M.'s family house, which has a visual character that can represent other houses in one area. The following discussion is in the form of (1) exterior-interior space, (2) form of building envelope, and construction materials.

\section{(1) Exterior-Interior Space}

The exterior space relates to the environment around the house (Prabowo, Al-Ghifari, Fadlilah, Pakuan, \& Zulfahmi, 2019). The circulation space connects the village road and the inside of the house, while the front yard with a distance of 2.5-4 meters is used to provide space if it is developed at any time by the government, besides that it functions to dry agricultural products such as rice and cocoa. The house is in the form of a single building, not overlapping so that there is space on the right and left of the building, which is called a transitional space. This space means space that is between other spaces, as physical support and connection and functions as a circulation (Rianty \& Jurumai, 2019). Outside the building, there is also a space under the house which functions as a multipurpose room for storing items such as jarai, steps, wood, etc., as well as a place for raising livestock such as chickens. Behind the house, there is a barn measuring $2 \times 2 \mathrm{~m}$ which functions to store rice and as a processing place to become rice and seeds. The yard at the back of the house functions as a place to grow vegetables and fruit so that residents can be more economical and cool the house. 
LOCAL WISDOM, Vol. 13 No. 1 January 2021

Local Wisdom Scientific Online Journal

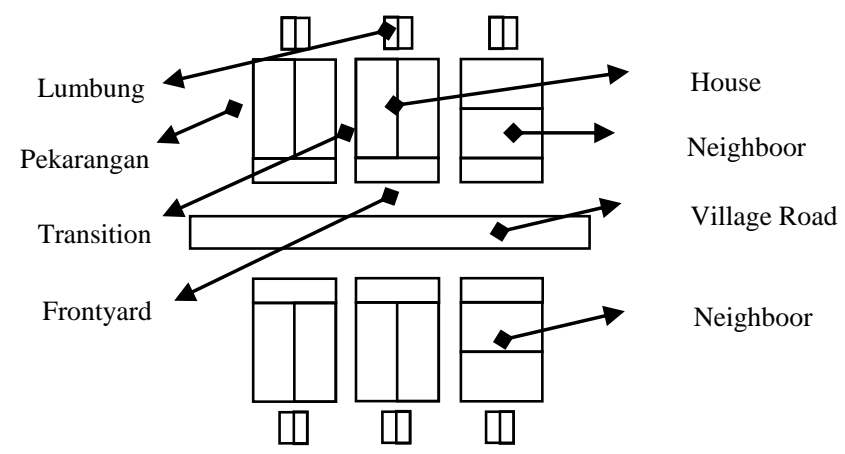

Figure 5. The position of the house against the surrounding environment or meso (Source: analysis result)

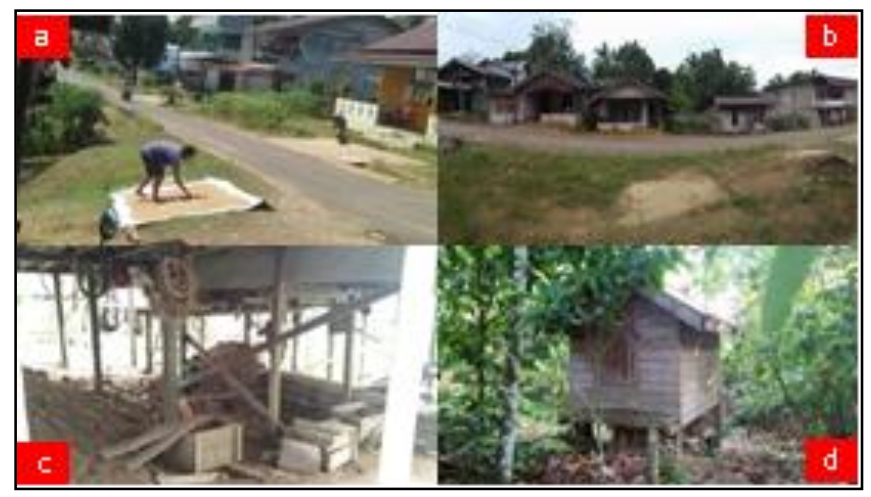

Figure 6. (a) front yard, (b) house arrangement, (c) basement of house, (d) lumbung (Source: analysis result)

Interior space as follows. The front of the house has a terrace, apart from being a place to relax, it is also a place to make handicrafts such as jarai, baskets, dykes, and so on. The living room is used to welcome guests, gather family members and a place to perform traditions such as "Gawai". The bedrooms are located in the middle of the building, or according to another pattern, only next to one side of the building. The back of the building has a kitchen. The typology of the house is taken based on the outline or generalization of the plan, because the formation of each house is not the same in terms of both the size of the plan and the visual appearance of the outside of the building, this morphology is caused by differences in the needs of the occupants or their socioeconomic abilities.
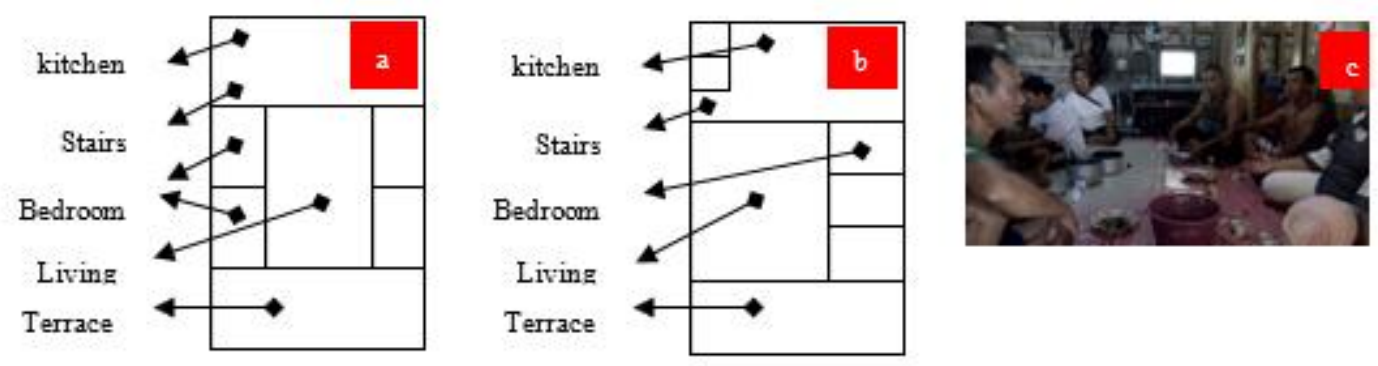

Figure 7. (a) the typology of conventional room configuration, (b) the plan after experiencing changes in spatial arrangement because it is flexible, (c) the living room is often used for cultural activities (Source: analysis result) 
(2) The shape of the building envelope and its construction

The building envelope is defined as the elements forming the outside of buildings such as foundations, walls, roofs, openings, and decorative ornaments. As discussed earlier, traditional houses have stilts in which some of the foundations go into the ground at 0.40.45 meters. The foundation and column material from Belian wood is stable and is not eaten by termites. Column dimensions about $15 / 15 \mathrm{~cm}$, the distance between columns is about 2 meters arranged in a grid. Floor and wall coverings made of Olai wood, especially in the living room and kitchen. Ceiling with a height of 3 meters from the floor and made of Tengkawang wood with a thickness that is almost the same as the gypsum ceiling. The door material in each part of the house is from Rengas wood. From this stage, it can be seen that most of the constituent elements are wood. The roof also has a wooden easel construction and a zinc roof covering, but in some houses. It is still found with a kisap roof (dried leaves). Here is a picture of the arrangement of the house.
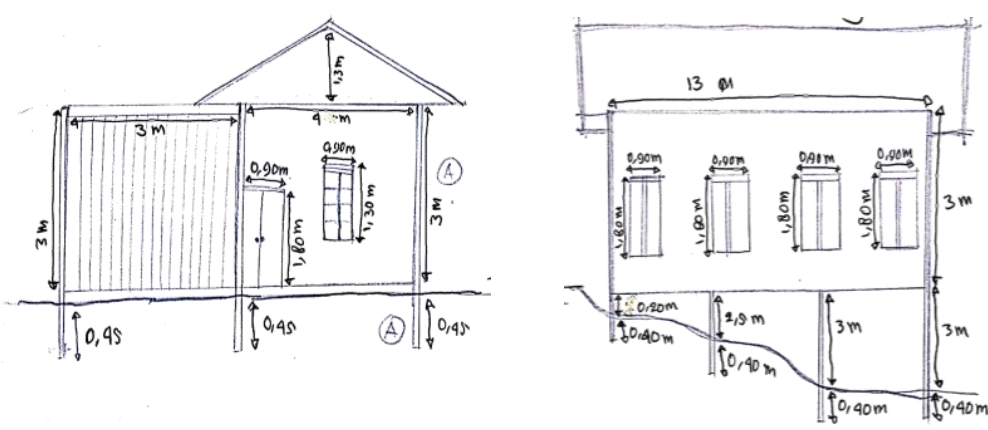

Figure 8. sketch of house section

(Source: analysis result)

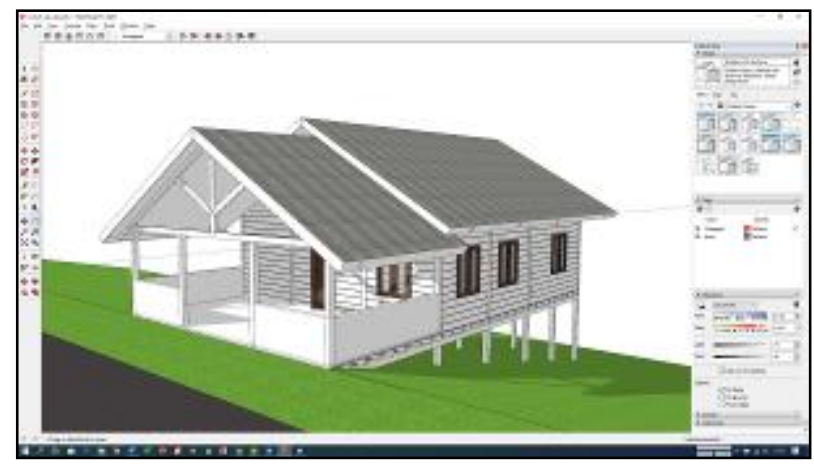

Figure 9. Picture of building envelope with Sketchup 2020 software

(Source: analysis result)

\section{Space Usage Activity}

Cultural activities using shared space are carried out within the scope of meso. The meso space in Balai Sebut village, especially in Perintis sub-village, there are village boundaries, churches, vegetation, agricultural land and plantation land. In Jangkang subdistrict, the cross is the village boundary between the Perintis sub-village and the other subvillages, which follow the road and are centered on the church. Agriculture is an essential aspect of life, especially livelihood. The location is a bit far from the centre of settlements so that the community has enough land to grow crops. In addition to the dominance of agriculture also plantations whose patterns follow the path of the road. Movement patterns 


\section{LOCAL WISDOM, Vol. 13 No. 1 January 2021 \\ Local Wisdom Scientific Online Journal}

from the results of cultural activities are mapped with behavioural mapping, the type of activity is a "Gawai" that is periodically carried out by local residents. "Gawai" is interpreted as a celebration of the harvest feast which symbolizes gratitude for agricultural products. In Jangkang Subdistrict, especially in Perintis sub-village, Balai Sebut village, there are seven types of "Gawai", the following are descriptions and uses of space:

(1) “Gawai" Rice field storage

"Gawai" Rice field storage is an activity that is devoted to storing rice in the rice barn. This process starts from the field, which is ngetam or harvesting (a), after which the rice is separated from the stem (this activity is carried out around the hut), then the rice can then be stored in a rice barn located in the hut (b). The space used is paddy fields, huts and rice barns, and the time of February-March.
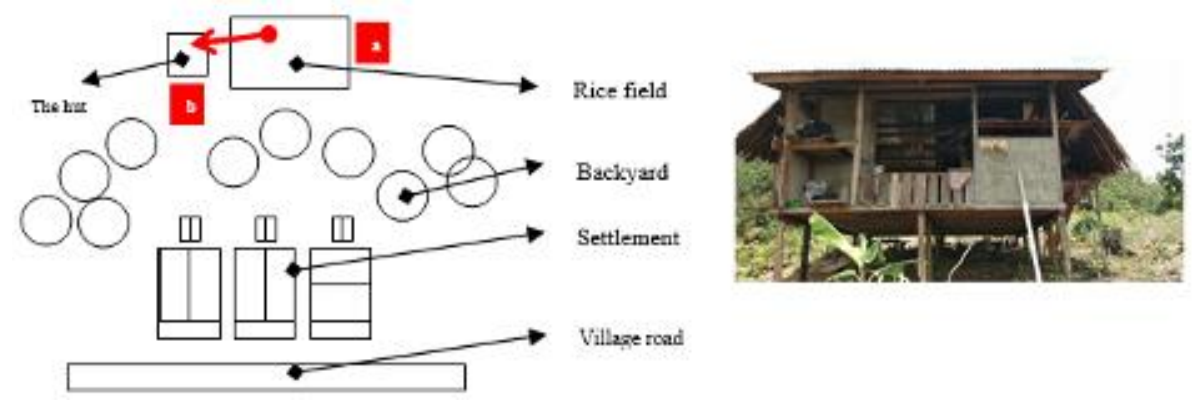

Figure 10. (left) sequence of "Gawai" Nyimpan Padi process, (right) the hut around the rice fields (2) “Gawai" Benih (Source: analysis result)

is a "Gawai" that is carried out before the process of planting seeds, seeds taken usually from rice stalks that have been planted before and in conditions that are ready to harvest, the seeds that have been taken must be stored in a particular place even local residents usually save their seeds in the rice barn or Jurong. The meaning of the "Gawai" Benih is the requesting that Pulang Gana be present when the "Gawai" procession takes place, the goal is that he blesses the seeds he wants to plant to flourish in the fields and fields. This process starts from the field (a) after which rice is brought to the hut (b) then blessed in the church in accordance with the tradition of the Dayak Jangkang tribe (c). There are two main churches in Balai Sebut Village: Gereja Santa Perawan Maria Diangkat Ke Surga and Gepembri Balai Sebut. After being blessed, then rice may be stored in a rice barn or jurong, both in the barn or in the paddy fields or in the back of the house (d). The space used rice barn in the hut then the church, and the time of activity around August-October.
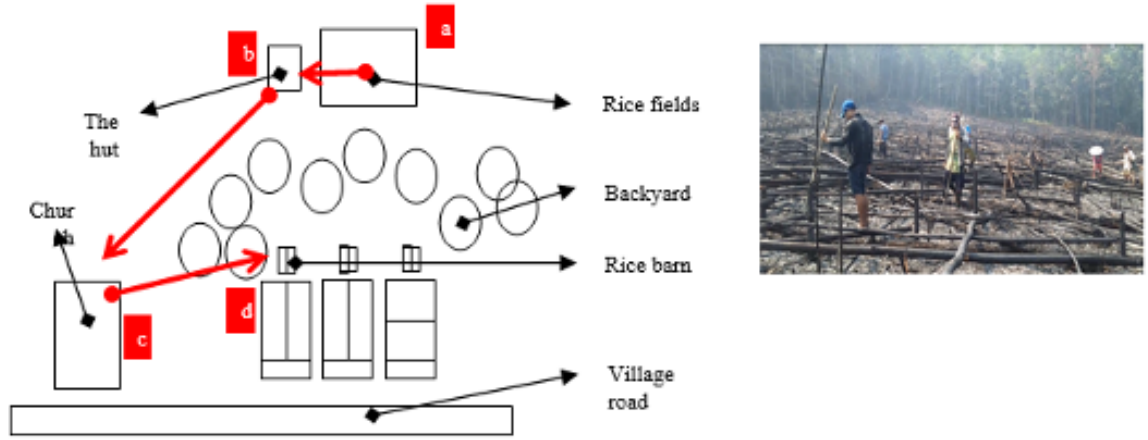

Figure 11. (left) sequence of "Gawai" Benih process, (right) after being blessed, rice is stored in a granary, fields cleared

(Source: analysis result) 
(3) “Gawai" Batu

This "Gawai" contain many symbolic meanings, which is closely related to the batu asah which means fertility. The "Gawai" Batu celebration is carried out at the start of the farming process. The process of "Gawai" batu starts from inside the hut, precisely taking rice in the rice barn or jurong to then rice seeds are planted in the fields. This "Gawai" activity is carried out from the start of the process at the start of the farming process to the harvest stage. The process itself can be described as follows: surveying the location of the fields, clearing the land, burning the fields, planting rice (during the process of planting rice carried out a ritual of the Dayak Jangkang tribe that is useful so that the rice to be planted will later flourish), cleaning grass in the fields, harvest. The space used is the hut and rice fields, and the time of activity around August-March.
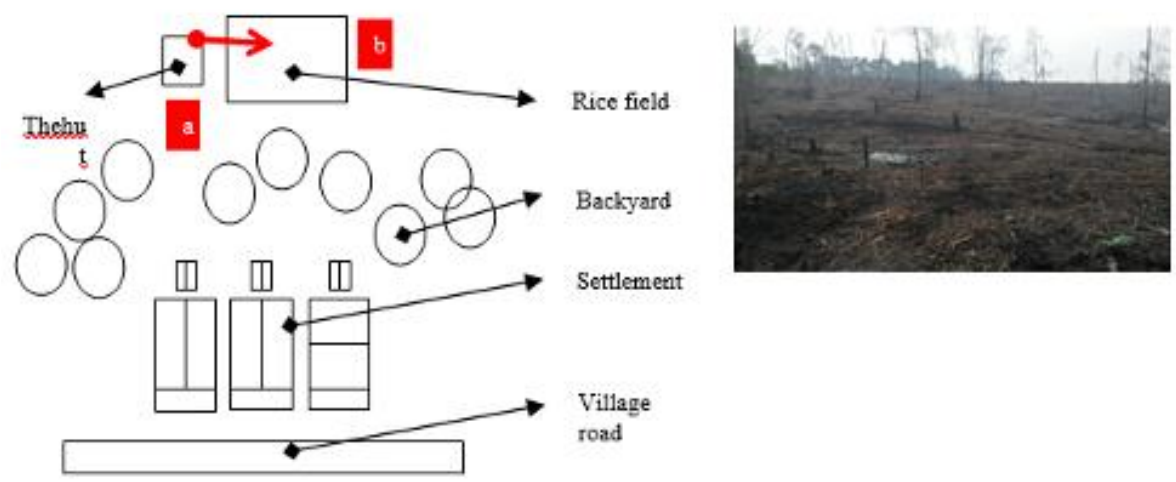

Figure 12. (left) sequence of "Gawai" Batu process, (right) land ready for planting rice seeds (Source: analysis result)

\section{(4) “Gawai" Burong}

is a form of gratitude to the god Burong. This "Gawai" is inseparable from culture to the god of war is the god Singalang Burong who according to the belief is a warlord, this "Gawai" is usually carried out within 3 days, as for implementation only at certain times such as during childbirth, marriage, and death ceremonies. This process starts from (a) a house that is carrying out a tradition (giving birth, marriage, and death ceremony) then continues to (b) a funeral called a tanjung, and people flock to go there with food and drink from their homes. -event to eat there and also as offerings, then the community can return to their respective homes to clean themselves. The space used is settlements and funeral, and the time of activities at any time when there are births, deaths, and marriages.

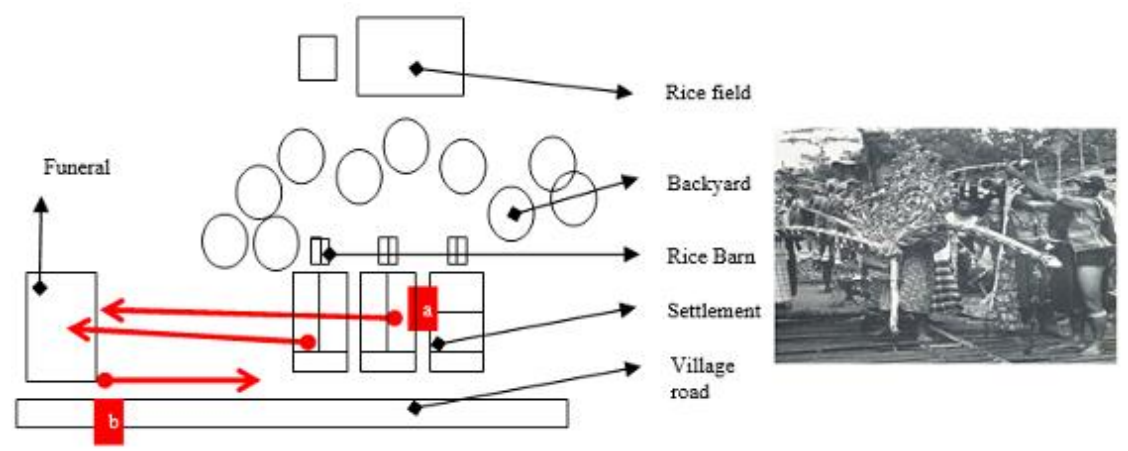

Figure 13. (left) sequence of "Gawai" Burong process, (right) activity procession (Source: analysis result) 
(5) “Gawai" Antu

is a preparation for a death ceremony that lasts for days involving all the close relatives. The process of this "Gawai" is only around residential areas, because in this "Gawai" only to give gifts to the person who has the most meritorious service in a death ceremony, the gift can be in the form of money or goods. The space used is between houses in a settlement, and the time of activity when there is a death ceremony.

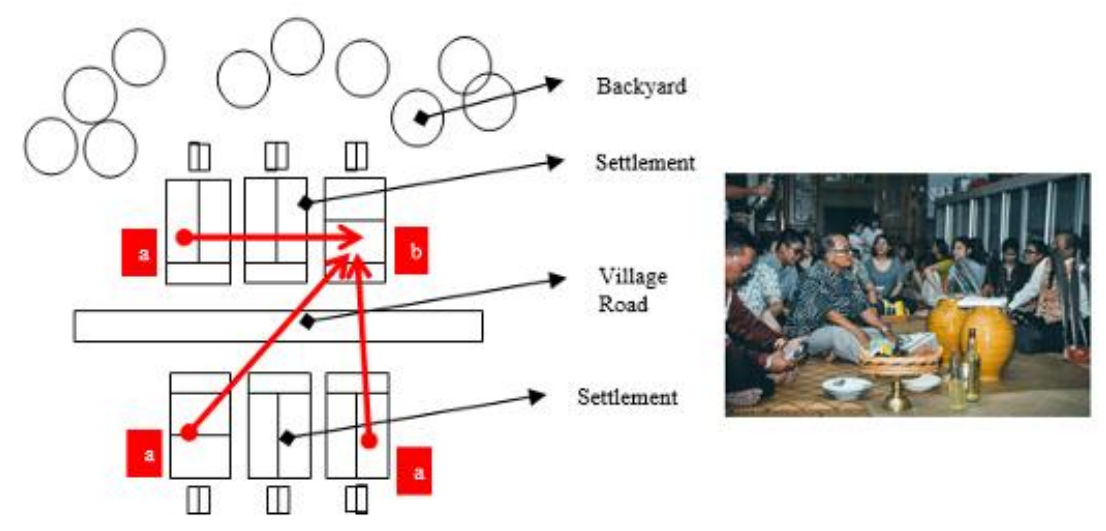

Figure 14. (left) sequence of the "Gawai" Antu process, (right) activity procession (Source: analysis result)

(6) “Gawai" Notokng

is a "Gawai" ceremony that aims to feed ancestral spirits. The implementation of "Gawai" Notokng is only done when a close relative wants to make a pilgrimage to the grave of a deceased family. This process starts from around the house (a) then is done inside the house (b), aims to feed ancestors or family members who have died with the rituals of the Dayak Jangkang tribe, then this activity is continued to the funeral (c) to make a pilgrimage to the tombs of members his family, after that the family members who make the pilgrimage pray and give offerings that they have brought to the funeral. The space used is between houses in a settlement and funeral, and time of activities when they want to visit the family grave.

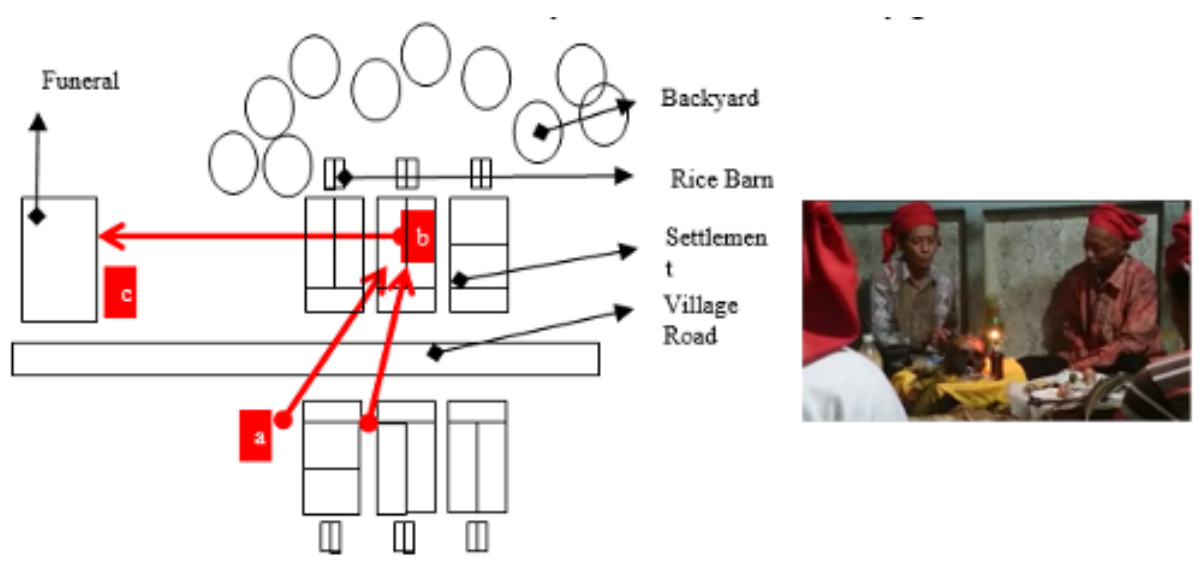

Figure 15. (left) sequence of the "Gawai" Notokng process, (right) activity procession (Source: analysis result) 


\section{(7) “Gawai” Syukuran Hasil Panen (Rice Harvest Thanksgiving)}

This "Gawai" is a religious ceremony by all Dayak tribes, including those in Jangkang sub-district, also this "Gawai" is one of the most important ceremonies for the Dayak tribe. Rice harvest thanksgiving is usually done after the rice harvest. This party has now been adjusted to the completion of school exams for elementary, middle and high school students so that they will not interfere with the learning process. This celebration is usually held between 3-7 days. The process is divided into 2 parts, this division is adjusted to the traditions that exist in each village in Jangkang sub-district in the form of Ngadap Data or Mokatn data, and Nsangi Ompuk. Ngadap Data is a ceremony to feed ancestors for the harvest that year. Villages that are still running this ceremony are Pisang Village, Tanggung Village, and Jangkang Benua Village. This tradition lasts for 3 days from preparation until the peak event which is held in the bath or river. While in Perintis sub-village, Balai Sebut village, the "Gawai" used is the Nsangi Ompuk "Gawai" tradition. This process begins with settlement (1) then family members must flock to go to the border of the village namely the cross (2) to carry out the tradition of closing the "Gawai", this tradition combines the rituals of the Dayak tribe with the religion they profess. The space used is the settlement and the village boundary (cross), and the time of activity around April-June.

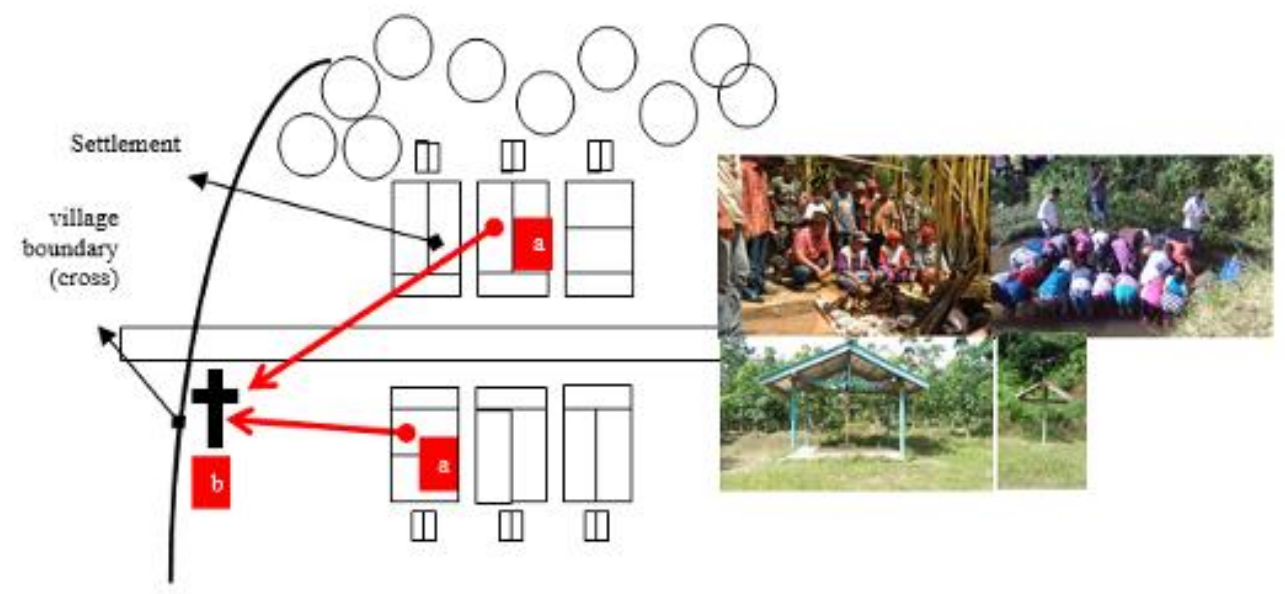

Figure 16. (left) sequence of the Harvest Thanksgiving process in Balai Sebut Village, (right) procession of activities and village boundaries

(Source: analysis result)

Besides "Gawai", there is another tradition in the Dayak tribe in the Perintis subvillage, Pongiruh, which means the tradition of the Dayak people who work as farmers together to help work in the forest, whether working on rice fields, gardens, or planting rice in the usual fields. It called nugal with a reply system without payment. From this research, it is further strengthened if the use of space is influenced by cultural activities in it (Setyabudi, 2011; Wesnawa, 2010). Apart from using space, cultural activities also lead to spatial transformation.

\section{CONCLUSION}

The Jangkang Bokidoh Dayak tribe is one of the tribes in Jangkang District which has unique and distinctive characteristics in terms of natural and cultural wealth, and differentiates it from other Dayak tribes in Sanggau Regency. Its cultural richness can be 


\section{LOCAL WISDOM, Vol. 13 No. 1 January 2021 \\ Local Wisdom Scientific Online Journal}

seen from its traditional architecture and cultural activities, namely "Gawai", or traditional ceremonies related to the life cycle. The architectural character of the traditional house is a transformation of the Kerak Betang formation. However, the spatial arrangement is more flexible due to space requirements, although typologically it is still the same, as the identity of the Dayak house, namely the construction of the stage. Another uniqueness is the settlement pattern that is oriented towards the village road, where the road is higher than the back yard of the house. This makes the stage construction have a height difference. The basement of the house becomes a multifunctional space, it can be used as a warehouse or a place to store furniture or pets such as chickens. The change in function was found when in ancient times the construction of the stage was made so that the house was safer from wild animal attacks or war between tribes. In the macro to micro space described above, there is a tradition that is still being preserved. A space will have meaning if there is an activity that involves that space, this indicates that the space is present. In this case, there are seven kinds of traditions ("Gawai") that are still preserved in Balai Sebut Village, which are related to the life cycle starting from the presence of ancestors, gratitude for the harvest, birth, death, and marriage. So, "Gawai" can be said to be a cultural activity that gives meaning to space in the traditional architecture of the Jangkang Bokidoh Dayak Tribe.

\section{REFERENCE}

Bambang, W., Ari, S., Susilo, K., \& Widya Fransiska Febriati, A. (2016). Cultural Approach of Sustainability in Dwellings Culture Riparian Community Musi River Palembang. DIMENSI (Journal of Architecture and Built Environment), 43(2). doi:10.9744/dimensi.43.2.85-92

Bhattacherjee, A. (2012). Social Science Research: Principles, Methods, and Practices, (2nd edition ed.). Tampa, Florida, USA: University of South Florida.

Creswell, J. W. (2014). Research design : qualitative, quantitative, and mixed methods approaches (4 ed.). New Delhi: SAGE Publications

Fitriyani, I., Antariksa, A., \& Wulandari, L. D. (2015). Penggunaan Ruang Pada Usaha Batik Tulis Di Kampung Batik Jetis Sidoarjo. RUAS (Review of Urbanism and Architectural Studies), 13(2), 47-59.

Ginzarly, M., Pereira Roders, A., \& Teller, J. (2019). Mapping historic urban landscape values through social media. Journal of Cultural Heritage, 36, 1-11. doi:10.1016/j.culher.2018.10.002

Indeswari, A., Antariksa, A., Pangarsa, G. W., \& Wulandari, L. D. (2013). Pola Ruang Bersama pada Permukiman Madura Medalungan di Dusun Baran Randugading. RUAS (Review of Urbanism and Architectural Studies), 11(1), 37-46.

Oliver, P. (1987). Dwelling The House Across The World, . UK: Phaidon Press Limited, Oxford.

Prabowo, A., Al-Ghifari, M. A. A., Fadlilah, F. N., Pakuan, G. M., \& Zulfahmi, M. H. (2019). Identifikasi Material Berkelanjutan Pada Ruang Luar Dan Ruang Dalam Bangunan Kantor. Jurnal Arsitektur ZONASI, 2(3), 160. doi:10.17509/jaz.v2i3.19492

Prijotomo, J., \& Pangarsa, G. W. (2010). Rong: Wacana Ruang Arsitektur Jawa. Ebook Engine. . 
"Gawai": Cultural Activities in the Shroud of Jangkang Bokidoh Dayak Tribe Traditional Architecture in Balai Sebut Village

Irawan Setyabudi, Dian Kartika Santoso, Katarina Albina

Putra, R. (2012). Dayak Djongkang : From Headhunters to Catolics, Studi dan Pendekatan Semiotika. Tangerang: UMN Press.

Rapoport, A. (1990). The Meaning of the Built Environment A Nonverbal Communication Approach. California: Sage Publications.

Rianty, H., \& Jurumai, L. P. (2019). Tipologi Rumah Adat Dayak. Journal Malige (Media Arsitektur Lintas Generasi).

Rushton, H., Silcock, D., Rogers, J., \& Schnabel, M. A. (2018, 13-15 June, 2018). The Tangible and Intangible: Interpreting Modern Architectural Heritage in Virtual Realities. Paper presented at the Tangible - Intangible Heritage(S) - Design, Social And Cultural Critiques On The Past, Present And The Future.

Santoso, D. K., \& Wikantyoso, R. (2018). Faktor Penyebab Perubahan Morfologi Desa Ngadas, Poncokusumo, Kabupaten Malang. Local Wisdom Scientific Online Journal, 10(2).

Setyabudi, I. (2011). Nilai guna ruang rumah tinggal suku Using Banyuwangi dalam kegiatan sosial, budaya dan agama. Local Wisdom Scientific Online Journal, 3(2).

Suhendro, R., Hanye, P., \& Patriantoro. (2019). Afiks dalam Bahasa Dayak Jangkang Kecamatan Jangkang Kabupaten Sanggau. Jurnal Pendidikan dan Pembelajaran, 8(3).

Sumalyo, Y. (1993). Arsitektur Kolonial Belanda di Indonesia. Yogyakarta: Gadjah Mada University Press.

Wesnawa, I. G. A. (2010). Dinamika Pemanfaatan Ruang Berbasis Kearifan Lokal di Kabupaten Buleleng Provinsi Bali. Forum Geografi, Vol. 24 (No. 1).

Wijaya, I. K. M. (2020). The Local Wisdom Study of Luan And Teben Concept on Balinese Ethnic Houses (Case Study: Balinese Ethnic Houses in Denpasar, Bali). Local Wisdom : Jurnal Ilmiah Kajian Kearifan Lokal, 12(2). doi:10.26905/lw.v12i2.4276 